\title{
Advantages of Football Tourism within the Framework of Sustainable Tourism (Model Study, a Mediterranean City, Antalya)
}

\author{
Burcu Beste Erdogru and Hacer Neyir Tekeli Yazici
}

\begin{abstract}
Inability to extend tourism in four seasons and the squeeze of economic activities adhered to tourism in a period changing through April - October months called as "tourism season" are the common problems of many tourism regions and investors. "Sustainable Tourism" activities for tourism investors to benefit from investments in tourism through the whole year have put a smile on tourism investors' faces. Football tourism is a product of such activities. "Football tourism", one of the branches of alternative tourism and expected to be the gateway for other tourism methods, used to energize the winter season titled "dead season" in tourism will be examined with face to face interviews along with the literature by this study.
\end{abstract}

Index Terms-Sustainable tourism, football tourism, alternative tourism in turkey, hotel management.

\section{INTRODUCTION}

Just like all operations that produce goods and services, tourism operations aim at achieving the highest possible profit by making the best use of available resources. Since production and consumption are simultaneous in tourism industry, the profitability of tourism operations is largely dependent on the demand that they will draw. Tourism demand can be easily influenced by the adverse conditions in the tourism environment [1].

Many factors including school holidays, industrial holidays, crisis, holiday times cause fluctuations in tourism demand. Accommodation operations are one of the main tourism operations that are intensely influenced by seasonal fluctuations. Operations that meet the requirements of tourists, who are travelling for different purposes, including accommodation, catering and partly entertainment, which is a moral requirement of social creatures, and that are structured according to the type of tourism event can be defined as accommodation operations [2]. The economic, social, cultural and political influences created by tourism, which is among the powerful and fast developing industries in a globalising economy and which is of particular concern to large crowds all over the world, are significant at national and international level.

Tourism demand towards a country is very sensitive to economic crises that reduce the expendable income to be saved for travelling, political developments that may damage the reputation of destination countries or regions and events that occur unexpectedly such as epidemics,

Manuscript received June 20, 2013; revised August 22, 2013.

Burcu Beste Erdogru is with Istanbul Kultur University (e-mail: b.erdogru@iku.edu.tr). natural disasters, wars and terror which threaten the security of life and property of tourism consumers [3]. Because tourism industry was adversely affected by terrorist activities that have been particularly more effective and violent since 1990, country governments have to take serious countermeasures. $1 / 4$ of the foreign trade deficit of Turkey is covered by tourism revenues. There are severe losses in other areas as well as long as Turkey and the sector is vulnerable to terrorist attacks. In that context (based on the demand fluctuations in tourism), supporting tourism movements as part of "Alternative Tourism" will reduce the demand fluctuations in this industry and minimize the deficits that are due to seasonal changes.

\section{A. Alternative Tourism and Turkey}

With its economic and social profitability, tourism sector has become a great potential and a merciless race started among the destinations. The most important tool in this race is to make different in tourism products and to develop an alternative tourism by using the available resources. In the implementation of these policies, particularly the development of alternative tourism became very important. Entering the tourism market with big capital investments in 1980's, Turkey experienced a fast and unplanned tourism development based on coastal tourism, that is, the sea, beach and sun trio. As time went by, changing tourism needs, tourism profiles and tourism trends caused Turkey to regress and slowdown in the market [4]. As a result of coastal tourism, there was huge destruction of coasts and the occupation capacity of coastal regions reached its limits. In order to cope with the new tourism trends, Turkey started product diversification and set out to establish alternative types of tourism.

Many alternative tourism options, and particularly congress tourism, are aimed at expanding Turkish tourism over four seasons. Among the types of tourism in this area are congress tourism, religious tourism, health tourism, and football tourism. If we examine Turkey in consideration of alternative tourism examples, it has some obvious advantages, such as: Turkey is favorable for culture tourism with its historical and cultural richness, climate, resources and unspoilt environment; there are about 1300 thermal springs in Turkey for thermal tourism; there are centers in Turkey at world standards suitable for winter sports; Turkey has suitable potential for tourism particularly with the Black Sea; there are fields in Antalya-Belek region allocated to golf tourism for tourists with high income group; there are facilities and convention centres for congress tourism, there are Islamic works as well as many churches, 
synagogues and other religious structures in Turkey which make it an attraction centre for religious tourism; there are national parks with features suitable for tourism; there are natural wonders such as Pamukkale and Cappadocia which are important for world heritage; there are many mountains including Ağrı, Erciyes, Kackar, Süphan, etc. which are valueable for mountaineering and mountain tourism ;there are areas suitable for "Eco tourism" and rural tourism; there are many rivers favorable for water tourism (rafting, canoeing, river skiing); proximity to sources of tourism because of geographical location product diversity as compared to competing countries; being an undiscovered destination for transcontinental markets; there are tourism product diversification included in the tourism marketing policies of the country; tourism product diversification helps spirit up domestic tourism (thermal tourism, tableland tourism, winter tourism, etc.). Apart from all these strengths, the existence of tourism destinations such as "football tourism" which attracts off-season demand from both inside and outside the country was able to overcome seasonal fluctuations and manage to expand tourism sector, the service industry in Turkey, over 4 seasons.

\section{B. Football Tourism as Part of Alternative Tourism}

Football, which is a branch of sport that is pursued by an increasing number of people in the world and in Turkey, is a big industry besides being an important mass sport. The fact that football is such an important sport event that draws the attention of crowds is the reason for many sectors, including tourism, to be interested in football and in revenues obtained from football.

Football is an important tourism event because of the spectators arriving to watch the organizations and a factor that vitalizes tourism sector with the camps. Other than by football teams, occupancy rates of accommodation facilities are also effected by press members who visit the camp areas to view the teams at least for once or to make news and by spectators who come to watch the matches or the training sessions.

According to Turkish tourism statistics, in the regions where football teams are hosted, the visiting times of football teams change among regions For instance, football teams prefer Anatolia and Black Sea between July and September in order to get prepared for the new season and Antalya, which is warm in winter, between January and March for their winter break camp. The period when football teams arrive is important particularly for Antalya.

Since the low season for accommodation facilities in Antalya is generally between October and December or January and March, the period when football teams arrive has increasing importance. However, the fact that although football teams arrive in January-March period the low season is also January-March period indicates that football teams are not sufficient by themselves to diminish the effects of seasonal demand fluctuations. In order to reduce the negative effects of seasonal demand fluctuations, football based tourism must be developed and more football teams must be encouraged to visit the region. Also congress and conferences, golf and other branches of sport, incentive tours, festivals and other tourism activities may be useful for reducing the negative effects of seasonal demand fluctuations.

Football tournaments in the camps are an important factor to develop football based tourism. Football tournaments that are organized during the periods when football teams arrive and the world famous teams which are invited to tournaments both make great contributions to the promotion of the region where the football teams are hosted and draw football teams to the region. Also the spectators who wish to watch the teams they support and the press members visit the region as well. Therefore, cooperating with the football federation and the football teams in the Turkish leagues in order to organize tournaments in places where football camps are located will be useful in ensuring that more teams have their camps in these regions.

During the times when football teams are in the region, they have a significant influence on the occupancy rates of the accommodation facilities and, although this influence is not as much as required, it still has non-negligible benefits for Turkish tourism.

\section{Hotels Involved in Football Tourism in Turkey}

According to the news by Doğan News Agency on 6 January 2012; many of the teams in the Super League have preferred Antalya for the winter break camp. Select Turkish sports clubs including Galatasaray, Trabzonspor, Beşiktaş, Manisaspor, Bursaspor, Ankaragücü, Kardemir Karabükspor, Gaziantepspor, Konyaspor, Eskişehirspor, Sivasspor, Bucaspor, Kasımpaşa, Gençlerbirliği, Kayserispor and İstanbul Büyükşehir Belediyespor have completed their winter break camp in Antalya.

The Skibbe teams Eintracht Frankfurt and Schalke which are among the well-known sports teams in the world are also among the teams that preferred Antalya as the camp area.

Among the foreign teams which have so far organised their camps in Antalya are famous clubs such as Werder Bremen, Bayern Leverkusen, Borussia Dortmund and Spartak Moskova. The increasing number of clubs reached over 1500 in the first 3 months of 2012. The Pro License Course and referee seminar organised by Turkish Football Federation through UEFA in order to prepare football coaches to work in Europe was organised in 2012 in the touristic hotels of Antalya. Hotels preferred by football teams are generally in the Mediterranean region and in Antalya. Among these hotels are Sueno Hotel Beach, Side Royal Atlantis Spa \& Resort, Selge Beach Resort Hotel, Sueno Belek Limak, Arcadia Hotel Fame Residence Lara Rixos Lares, Titanic de Luxe Resort, Emirhan Hotels/Xanthe, WOW Kremlin Palace, Starlight Hotel, Maxx Royal, Voyage Hotel, Ela Quality Hotel.

\section{METHODOLOGY}

\section{A. The Interview}

Interviews are one of the most important methods that are used to collect information. In the present research face to face interview with the officer of the selected pilot hotel aims:

The importance of "football tourism within the framework of sustainable tourism in Antalya, Turkey" 
(chosen region and city).

\section{FINDINGS}

\section{A. Awareness of Sustainability and Sustainable Tourism}

The World Tourism Organisation (WTO) defined sustainable tourism as early as 1988 as 'leading to management of all resources in such a way that economic, social and aesthetic needs can be fulfilled while maintaining cultural integrity, essential ecological processes, biological diversity and life support systems [5].

The type of tourism based on football camps has been a renovation for tourism industry in reducing the adverse effects of seasonal demand fluctuations in tourism. Football tourism, which is similar to congress tourism in the field of alternative tourism, has minimised the blood loss of tourism in the off-season period.

B. Interview with the 5 Star Pilot Hotel Selected in the Mediterranean City of Antalya Which Practices Football Tourism in Turkey Questions and Answers; Your Hotel Has Been Making Comprehensive Tourism Efforts Related to Camps of Football Teams. Can You Tell us about This Alternative Type of Tourism?

Time to time our hotel hosts football teams for camps. At the end of January when schools are in semester holiday we will entertain school groups. At the same dates there will be tennis groups. There are further football teams from Russia. During this period, first league teams from Bulgaria and Romania will be in our hotel for camping. We will also be hosting many football teams including women's football teams of Turkic Republics. With alternative types of tourism we will expand our occupancy over 4 seasons.

1) Do you expect an increase in football camp organisations in 2013 as compared to 2012?

We can say that the reservation levels are almost the same. The same teams from last year have preferred us for camping again and other teams have preferred other hotels in Antalya. We had the chance of hosting Konyaspor, Scotch team Quenpark and Rubin Kazan from Russia in our hotel.

2) Can you tell us about some sports organisations in your hotel and the teams you accommodated as well as your future objectives?

In April 2007, a baseball field was prepared in our sports complex for the first time in Turkey and a baseball tournament was organised among the junior national teams of Turkey -Germany - Russia- The Netherlands and Bulgaria. In March 2007, a rugby field was prepared in our sports complex for the first time in Turkey and Russian and Ukrainian teams were here for camp. Our facility hosted World Schools' Football Championship (ISF) in April 2009 with the participation of 40 teams. Our hotel, which sets up new markets and achieves many firsts as a result of the marketing work and the tours we make with our foreign partners, has been hosting football teams from many countries of the world every year. These countries include Brazil - USA - South Korea - Germany - The Netherlands - Switzerland - Sweden -Norway - Denmark - Faroe Islands - Hungary - Romania - Bulgaria - Croatia - Czech
Republic - Slovakia - Slovenia - Russia - Kazakhstan Ukraine. Our objective for 2013 is to accelerate the sports organizations we have made before.

3) Antalya is making a name for itself in football tourism day by day. What is the reason for the preference of Antalya?

We have been witnessing pleasing developments for Turkey in football tourism. We know that many European clubs prefer Spain, Italy and France for camp. However, these clubs have now turned to Turkey. Antalya is mostly preferred by German football teams. In 2012, teams including Shalke, Werder Bremen, and Köln came to Antalya for camp. In 2012 season there were many tournaments in Antalya. The climate features of the Mediterranean Region and particularly of Antalya, the warm weather in winter months and the obvious premium features of the tourism investments in Antalya have enriched this region in terms of football tourism.

4) And finally can you tell us about your preparations for the summer season?

We have completed our maintenance and repair work in some parts of our hotel for summer season, just like the other hotels do. We made the gardening and outer facade work and completed all missing things. We are ready for summer. We will be having normal football season and welcoming our summer guests from 1st May 2013.

\section{DISCUSSION AND CONCLUSION}

It is a global reality in the field of tourism that the offseason occupancy rates in tourism investments is supported by alternative types of tourism. Although football tourism is not at the desired levels yet, it is a visional reality in the field of tourism that the growth rate of alternative types of tourism will be accelerated in the future. The favourable climate conditions in the Mediterranean region and the quality tourism investments have made Antalya a star in this field. Among the objectives of Turkish tourism are building facilities in regions with warm climate and especially in the mountain regions not only in offseason period but also in summer season and expanding football tourism over 4 seasons. Football tourism may be further improved by investments in the field of football tourism, by promotion and most importantly by units set up by accommodation facilities consisting of football experts. Government subsidies are also very important for developing football tourism. Football tourism may be developed particularly through granting loans and tax reductions to operations that will make football investments and by facilitating the allocation of fields on which the buildings will be made [6]. As a result it is obvious that the football teams have made positive contributions to the full capacity and income for the tourism hotel investments.

\section{REFERENCES}

[1] S. A. Roney, Turizm Bir Sistemin Analizi, 1st ed. Istanbul: Detay Publications, 2011, pp. 31

[2] H. Olali and M. Korzay, Otel Isletmeciligi, 2nd ed. Istanbul: Yon Publications, 2000, pp. 7-8

[3] F. Witt, M. Brooke, and P. J. Buckley, The Management of International Tourism, New York : Routledge, 1995, pp. 43C. 
[4] Oner, Travel Commerce, Istanbul, Literatur Publications, 1997, pp. 20

[5] C. Ashley, D. Roe and H. Goodwin. Pro-Poor Tourism Report No. 1. Pro-Poor Tourism Strategies: Making Tourism Work For The Poor. pp. $2.2 \quad$ [Online]. Available: http://www.pubs.iied.org/pdfs/9078IIED.pdf

[6] O. Usta, Evaluation of Investment Projects, Istanbul, Detay Publications, 2001, pp. 180-181

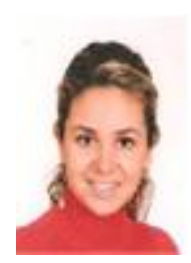

Burcu Beste Erdogru was born in Istanbul in 1978. She got her bachelor of arts degree on Economics from Istanbul University, Faculty of Economics and master's degree on international commerce from Istanbul Commerce University Institute of Social Sciences with the thesis: "The Importance of Marketing Information Systems and Market Research in International Marketing". In 2001 she obtained "Global Business and Management" and "E-commerce" Certificates from University of California Santa Barbara. In 2010 she received her Ph.D. on Economics Theory from Marmara University, Institute of Social Sciences with the thesis subject: E-Commerce During The Transmission to Integration within, The Scope of New Economy, An Example In Turkey". Erdogru started working as a research assistant in 2002 in Istanbul Commerce University and until 2008 she worked as teacher assistant, a lecturer and a senior lecturer in the same university on economics, macroeconomics, international economics and tourism and hotel management. Since 2009 she has been a member of the board of directors of Vocational School of Business Administration in Istanbul Kultur University, working as an associate professor and besides giving lectures on economics and tourism, she is the head of Tourism and Hotel Management Program. Her major research interests include tourism industry, tourismeconomics and innovation in tourism.

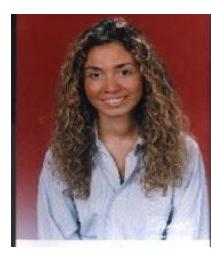

Hacer Neyir Tekeli Yazici was born in Istanbul in 1975. She got her bachelor of arts degree on Art History from Istanbul University Faculty of Literature and master's degree on Tourism Management from Istanbul University Institute of Social Sciences with the thesis: "Tourism in Edirne and Evaluation of Edirne Tourism “.She alos got the second master's degree of managerial economics from Istanbul Culture University, Institute of Social Sciences with the thesis subject: "Decision support system for the evaluation of investment projects in tourism "Neyir Yazıcı started working as a research assistant in 2000 in Istanbul University than in 2002 she started working as a research assistant in 2002 in Istanbul culture University and still worked as an associate professor Besides giving lectures on art history and tourism, She is the head of Marketing Program and lucturer of Tourism and Hotel Management Program. Her major research interests include tourism industry, tourism investments and project management. 